\title{
KONSEP KELUARGA SAKINAH SEBAGAI SOLUSI ALTERNATIF KONFLIK RUMAH TANGGA
}

\author{
Iwan Falahudin \\ Balai Diklat Keagamaan Jakarta \\ e-mail:iwanaja1011@gmail.com
}

\begin{abstract}
There are conflicts between husband and wife that are closed, and some are open, but the ends remain the same, many of which end in divorce. Therefore we need a concept that can be used as a guide to control, reduce, and or at least minimize the possibility of conflicts that can grow, and or even those that have already emerged. This paper was written to describe the concept of the sakinah family according to the government, in this case the ministry of religion. This paper uses a qualitative approach with descriptive methods. The data collection technique is to take data from various digital literacy sources, while the data analysis technique uses deductive techniques. The general conclusion of this study shows that the concept of the sakinah family is a happy family that interacts with a pattern of mutual need, love and affection, standing on a legal marriage, with the ability to carry out its obligations and rights, accompanied by adherence to religious teachings and state law. This concept is a knowledge that must be understood in depth, accompanied by a strong will to practice it, and a maximum ability to implement it.
\end{abstract}

Key words: Sakinah family; conflict; household.

\begin{abstract}
Abstrak
Konflik antara suami istri itu ada yang tertutup, dan ada yang terbuka, akan tetapi ujungnya tetap sama, banyak yang berakhir dengan perceraian. Karena itu diperlukan sebuah konsep yang dapat dijadikan pedoman untuk mengendalikan, meredam, dan atau setidaknya meminimalkan kemungkinan konflik yang dapat tumbuh, dan atau bahkan yang sudah muncul. Makalah ini ditulis untuk mendeskripsikan konsep keluarga sakinah menurut pemerintah, dalam hal ini adalah kementerian agama. Tulisan ini menggunakan pendekatan kualitatif dengan metode deskriptif. Teknik pengumpulan datanya adalah mengambil data dari berbagai sumber literasi digital, sedangkan teknik analisis datanya menggunakan teknik deduktif. Kesimpulan umum penelitian ini menunjukkan bahwa konsep keluarga sakinah adalah keluarga bahagia yang berinteraksi dengan pola saling membutuhkan, mencintai, dan menyayangi secara berimbang, berdiri di atas perkawinan yang sah, dengan kemampuan untuk menjalankan kewajiban dan haknya, diiringi dengan ketaatan pada ajaran agama dan hukum negara. Konsep tersebut merupakan suatu pengetahuan yang harus dipahami secara mendalam, diiringi dengan kemauan yang kuat untuk mempraktikkannya, dan kemampuan yang maksimal untuk melaksanakannya.
\end{abstract}

Kata kunci: Keluarga Sakinah; konflik; rumah tangga. 


\section{PENDAHULUAN}

Pendapat, kebutuhan, dan keinginan setiap orang sering kali berbeda, bagi sepasang manusia yang saling mencintai sekalipun, bahkan termasuk pasangan suami istri. Perbedaan itu bisa menimbulkan perselisihan. Perselisihan yang berkepanjangan bisa menimbul-kan pertentangan, dan pertentangan yang berkelanjutan itu bisa menimbul-kan konflik. Konflik adalah konseku-ensi natural dari terjalinnya suatu interaksi (Susan Novri, 2014: XXIII).

Konflik dapat muncul karena adanya akal dan hawa nafsu pada diri manusia. Pola pikir yang berbeda saja dapat menyebabkan tumbuhnya konflik, baik konflik internal (dalam diri sendiri) maupun konflik eksternal (dengan pihak lain). Hawa nafsu yang berbeda pun berpotensi untuk memunculkan konflik. Apa lagi ketika pola pikir dan hawa nafsu berkumpul sekaligus dalam satu jiwa, tentu saja akan sangat berpeluang untuk menimbulkan konflik, bahkan bisa menjadi konflik yang berkepanjangan.

Konflik artinya percekcokan, perselisihan, atau pertentangan (KBBI, 2008;799). Bisa juga bermakna benturan atau tabrakan. Secara umum, konflik adalah suatu peristiwa atau gejala social yang banyak terjadi berupa perten-tangan atau pertikaian antar individu, atau individu dengan kelompok, atau kelompok dengan kelompok, atau kelompok dengan pemerintah. Pema-haman mudahnya, konflik adalah per-saingan, ketidakcocokan, pertentangan antara satu pihak dengan pihak lainnya (Daniel, Webster, dalam Rusdiana, 2015: 162).

Konflik itu dapat muncul di mana saja, atau kapan saja, tanpa mengenal batas ruang dan waktu, termasuk dalam kehidupan berumah tangga. Sepasang manusia berlainan jenis yang pada awal perjumpaannya atau pada masa awal diperjumpakannya dapat merasa saling tertarik, dan berlanjut pada proses khitbah / lamaran, lalu akhirnya menikah. Pada saat itu mereka merasa bahwa hidupnya itu bahagia. Akan tetapi seiring dengan berjalannya waktu, perbedaan pendapat dan atau keinginan antara keduanya menjadi semakin tampak jelas. Perbedaan antara keduanya itu jika tidak dikelola dengan baik, dapat memunculkan konflik, baik tertutup maupun terbuka.

Konflik dalam rumah tangga itu adalah suatu fakta yang sudah diketahui secara umum, dan dirasakan oleh banyak pasangan suami istri.

(https://id.theasianparent.com/konfli

k-rumah-tangga). Bukti empirisnya adalah angka perceraian yang sepertinya tidak terkendali dan terus meningkat dari tahun ke tahun.

Berdasarkan data Badan Peradilan Agama Mahkamah Agung sebagaimana dikutip kompas.com, tentang angka perceraian di Indonesia, khususnya yang beragama Islam. Pada tahun 2019 mencapai 480.618 kasus. Angka tersebut mengalami peningkatan setiap tahun sejak tahun 2015 (394.246 kasus), 2016 (401.717 kasus), 2017 (415.510 kasus), dan 2018 (444.358 kasus). Agustus 2020, jumlahnya sudah menca-pai angka hingga 306.688 kasus (https://nasional.kompas.com/read/2 020/09/13/10294341/tekan-angkaperceraian-kemenag-jalin-sinergitaspenguatan-ketahanankeluarga?page $=$ all).

Angka perceraian sebagaimana tersebut merupakan tingkat yang 
cukup tinggi. Berkisar antara 15-25\% dari angka perkawinan yang berjumlah seki-tar 1,8 hingga 2 jutaan per tahunnya

(https://kumparan.com/kumparanne ws/kami-membandingkan-jumlahpernikahan-dan-perceraian-diindonesia-1sKM5fAHafr/full).

Bahkan trend pada saat ini, kasus perceraian yang terjadi tidak hanya diajukan oleh pihak suami, melainkan juga banyak gugatan cerai yang dilayangkan oleh pihak istri.

(http://indonesiabaik.id/infografis/ju mlah-kasus-perceraian-di-indonesiamemprihatinkan). Fakta yang seperti ini tentu saja mengundang keprihatinan dari berbagai kalangan, terutama dari kementerian agama.

Semua perceraian yang terjadi itu penyebab utamanya adalah konflik yang berkepanjangan dan atau tidak terkendali. Ada 7 jenis konflik yang mendominasi angka perceraian itu, yakni: Pertengkaran; 46,6\%, ekonomi; $28,2 \%$, meninggalkan pasangan; $18,2 \%$, KDRT; 2,1\%, mabuk, madat/candu, judi, dan zina; 2,1\%, poligami; $0,3 \%$, kawin paksa $0,2 \%$, lain-lain; $2,2 \%$. (https:/ / lokadata.id/artikel/tingkatperceraian-lebih-tinggi-dariperkawinan).

Pihak kementerian agama tentu saja merasa terpanggil dan turut bertanggung jawab atas merebaknya berbagai konflik dalam rumah tangga itu, apa lagi yang bahkan berujung pada perceraian. Salah satu efek konflik dalam rumah tangga itu adalah anak. Anak dalam sebuah keluarga adalah seorang pemerhati dan pengamat yang tekun, seorang peniru ulung dari segala ucapan, sikap, dan tindakan kedua orang tuanya. Anak adalah amanat yang harus dididik dengan sebaik-baiknya (Inpres Nomor 3 Tahun 1997). Ada banyak kasus kenakalan anak dan remaja, bahkan sampai tingkat kriminal yang berasal dari keluarga yang tidak harmonis, keluarga yang didalamnya sering terjadi konflik rumah tangga.

(http://journal.unpad.ac.id/pros iding/article/viewFile/14393/6947).

Kementerian agama telah membuat sebuah program yang diharapkan dapat mengantisipasi, meredam dan mengendalikan serta meminimalkan potensi konflik dalam rumah tangga, serta kenakalan anak dan remaja. Tujuan program tersebut adalah menjadi salah satu solusi alternatif atau salah satu jalan keluar yang bisa menjadi pegangan bangsa Indonesia khususnya umat Islam, baik yang belum menikah maupun yang sudah menikah. Program tersebut bernama pembinaan gerakan keluarga sakinah (KMA Nomor 3 Tahun 1999).

Dalam rangka mengantisipasi, meredam dan mengendalikan serta meminimalkan potensi konflik dalam rumah tangga, serta kenakalan anak dan remaja itu, maka kementerian agama meluncurkan sebuah program yang diharapkan dapat menjadi solusi alternatif, atau salah satu jalan keluar yang bisa menjadi pegangan bangsa Indonesia khususnya umat Islam, baik yang belum menikah maupun yang sudah menikah. Program tersebut bernama pembinaan gerakan keluarga sakinah (KMA Nomor 3 Tahun 1999).

Secara umum program pembinaan gerakan keluarga sakinah itu memang bukan merupakan jaminan tunggal untuk menghilangkan konflik rumah tangga, tapi setidaknya diharapkan dapat mengurangi intensitas konflik (Falahudin, Iwan, 2020, 
https://wawasan.bdkjakarta.id/index.php Lwawasan/article/view/42/17 ). Selain itu diharapkan pula dapat mengerem angka perceraian, dan mengendalikan angka dekadensi moral di-kalangan generasi muda, sebagai salah satu out come-nya (Kepdirjen Bimas Islam \& Urusan Haji, No. 71 Tahun 1999).

Diharapkan pula dapat mengerem angka perceraian, dan mengendalikan angka dekadensi moral dikalangan generasi muda, sebagai salah satu out come-nya (Kepdirjen Bimas Islam \& Urusan Haji, No. 71 Tahun 1999).

Program pembinaan gerakan Keluarga sakinah sebagaimana yang dicanangkan kementerian agama bukanlah berarti keluarga yang tanpa konflik. Dalam sebuah interaksi, konflik adalah suatu keniscayaan. Misalnya dapat berasal pendapat yang berbeda, keinginan yang tidak sama, persoalan hidup yang datang silih berganti, baik dari aspek sosial, ekonomi, budaya, ataupun yang lainnya (Falahudin, Iwan, 2020, https://wawasan.bdkjakarta.id/index. $\mathrm{php} /$ wawasan/article/view/42/17 ). Fokus dari program ini adalah bagaimana sebuah keluarga dapat menghadapi, mengelola, atau menyelesaikan masalah dalam kehidupan rumah tangganya dengan baik (Juknis Pembinaan Gerakan Keluarga Sakinah, 2011).

Keluarga sakinah awalnya adalah dua sejoli yang bertemu, berjanji, dan bersatu pada satu ikatan cinta dan kasih sayang, berlandaskan keimanan dan ketakwaan untuk meraih kehi-dupan rumah tangga yang bahagia baik di dunia maupun di akhirat kelak. Ikatan sebagamana tersebut di atas adalah ikatan yang sangat kuat, tidak mudah putus, tidak gampang lepas ketika ujian dan cobaan datang melanda dalam bahtera rumah tangganya (Q.S. 4, An-Nisa; 21).

Bagi keluarga sakinah, setiap masalah yang datang akan banyak dilihat pada sudut persamaannya, dihadapi dengan kesabaran, ditangani dengan ketelitian, dipikirkan dengan matang segala sebab dan akibatnya. Sehingga dapat menemukan solusi yang maslahat dan manfaat bagi semua pihak (Undang-Undang Nomor 1 Tahun 1974, Bab I, Pasal I).

Berbeda dengan keluarga yang tidak sakinah, setiap masalah akan banyak dilihat pada titik perbedaannya. Persoalan kecil pun dapat dibuat menjadi besar, apalagi persoalan yang besar. Biasanya jika mendapatkan masalah, walaupun hanya masalah kecil, maka akan dihadapi dengan emosional, dan cenderung tanpa ber-pikir panjang lagi. Akibatnya bisa menjadi pertengkaran yang saling me-lukai, saling mencaci, saling membenci, saling menjauh, dan sulit menemukan solusi. Sehingga dapat berakhir dengan kekecewaan, kesedihan, keputus-asaan, dan bahkan perceraian.

Berbagai macam persoalan yang melanda keluarga non sakinah itu, bukan hanya berakibat buruk pada aspek psikologis dan sosial saja sebagaimana tersebut di atas, tetapi juga bisa berdampak buruk bagi kesehatan tubuh.

(https://nationalgeographic.grid.id/re ad/13900431/pernikahan-yang-tidakharmonis-berdampak-buruk-padakesehatan).

Dalam rangka menjalankan kebijakan kementerian agama tentang 
pembinaan gerakan keluarga sakinah, maka Balai Diklat Keagamaan Jakarta mengadakan pendidikan dan pelatihan bagi pembina gerakan keluarga sakinah. Sasaran utamanya adalah pembina gerakan keluarga sakinah utusan dari beberapa kecamatan.

Masalah dalam tulisan ini adalah belum maksimalnya pemahaman para pembina keluarga sakinah pada konsep keluarga sakinah versi pemerintah yang berkaitan dengan dalil-dalil teologis berbasis kitab kuning/klasik. Data ini diperoleh dari hasil pre test para peserta diklat pembina keluarga sakinah (Falahudin, I. (2020). KOMPETENSI PENGETAHUAN PEMBINA GERAKAN KELUARGA SAKINAH. Wawasan: Jurnal Kediklatan Balai Diklat Keagamaan Jakarta, 1(1), 110-117. Retrieved-from https://wawasan.bdkjakarta.id/index.php/waw asan/article/view/42 ).

Tujuan penelitian ini adalah untuk mendeskripsikan konsep keluarga sakinah menurut versi pemerintah dalam hal ini kementerian agama, yang dikaitkan dengan dalil-dalil teologis berbasis kitab kuning/klasik.

\section{METODE}

Pendekatan penelitian yang penulis pilih dalam penyusunan tulisan ini adalah pendekatan kualitatif. Pendekatan ini diambil karena penulis ingin mendapatkan gambaran hasil penelitian ini berupa uraian yang detil dan jelas. Metode penelitian dalam tulisan ini adalah deskriptif. Disusun untuk mendeskripsikan konsep keluar-ga sakinah menurut versi pemerintah/ kementerian agama yang dikaitkan dengan dalil-dalil teologis berbasis kitab kuning/klasik.
Teknik pengumpulan data dalam penyusunan makalah ini adalah dengan cara mengambil data dari berbagai sumber literasi digital.

Analisis data mengandung dua unsur penting yakni mendeskripsikan data yang telah diperoleh dan dikumpulkan, lalu dikelompokkan sesuai dengan karakteristiknya baik melalui pengkodean maupun tabulasi data sehingga tergambar bagaimana kondisi yang ada. Teknik analisis data dalam penyusunan karya tulis ini adalah deduktif. Suatu analisis dari umum ke khusus. Penarikan kesimpulan dari keadaan yang umum menuju kepada yang khusus, atau menemukan sesuatu yang khusus dari kondisi yang umum.

\section{HASIL DAN PEMBAHASAN Hasil Penelitian}

Hasil penelitian berupa kajian pustaka ini menunjukkan bahwa konsep keluarga sakinah menurut versi pemerintah adalah:

"Keluarga yang dibina atas perkawinan yang sah, mampu memenuhi hajat hidup spiritual dan material secara layak dan seimbang, diliputi suasana kasih sayang antara anggota keluarga dan lingkungan-nya secara selaras, serasi, serta mampu mengamalkan, menghayati dan memperda-lam nilai-nilai keimanan, ketaqwaan dan akhlak mulia". (Kepdirjen Bimas Islam \& Urusan Haji, No. 71 Tahun 1999, Bab III, Pasal 3).

Sedangkan menurut temuan penulis berdasarkan identifikasi literatur kitab kuning/klasik dan Kepdirjen Bimas Islam dan Urusan Haji, keluarga sakinah adalah: Keluarga yang saling membutuhkan, mencintai, me-ngasihi dan menyayangi secara ber-imbang, dibangun di atas perkawinan yang sah, dengan 
kemampuan untuk memenuhi kebutuhan fisik, psikis, social, dan spiritual secara normal.

\section{Pembahasan Penelitian}

Beberapa syarat untuk menjadi keluarga sakinah menurut Kementerian Agama: Syarat pertama untuk menjadi keluarga yang sakinah adalah memiliki bukti perkawinan yang sah menurut agama dan undangundang negara. Kedua, memiliki kemauan dan kemampuan menjalankan kehidupan beragama yang baik, dan dapat memenuhi kebutuhan kebutuhan itu yang mendasar seperti: makan, minum, tidur, pakaian, dan tempat tinggal yang layak. Ketiga, kondisi kehidupan berkeluarga yang berlandaskan rasa saling mengasihi dan menyayangi secara berimbang antara satu dengan yang lainnya. Keempat, memiliki tekad yang kuat untuk saling meningkatkan keimanan, ketakwaan dan akhlak mulia (Kepdirjen Bimas Islam \& Urusan Haji, No. 71 Tahun 1999, Bab III, Pasal 3).

Beberapa syarat untuk memiliki keluarga yang sakinah menurut kitab kuning/klasik adalah: Pertama, saling menyukai dan menaruh kepercayaan, serta tenang dalam menghadapi berbagai situasi (Al-Munawir, Ahmad, Warson, tt. ; 646). Kedua, memiliki kecenderungan dan keberpihakan antara keduanya (Al-Alusy, Syihabuddin Mahmud bin Abdillah Al-Husainy, tt; 348). Ketiga, berkumpul pada satu tempat yang telah disepakati (Hayyan, Abu Hayyan Muhammad bin Yusuf bin Ali bin Yusuf, tt; 76-77), (As-Syaukani, tt; 464), (AlMahalli Jalaluddin, dan As-Suyuthi Jalaluddin, tt; 429). Keempat, hubungan antara keluarga berlandaskan pada sikap saling menuruti dan mematuhi, ramah dan menghargai, serta saling menyenangi dan menyukai (Al-Mawardi, Abul Hasan Ali, bin Muhammad, bin Muhammad, bin Habibil Bisri, Al-Baghdadi, tt; 315).

Kedua uraian di atas, memberikan gambaran bahwa keluarga sakinah itu adalah keluarga yang dibangun atas perkawinan yang sah menurut agama dan negara, yang di dalamnya ada rasa saling membutuhkan, saling memberi dan menerima, baik kebutuhan jasmani maupun rohani sesuai kemampuan dan kelayakan.

\section{Konsep Keluarga Sakinah}

Kata 'sakinah' sebenarnya sudah ada sejak lama, sejak ribuan tahun yang lalu, sejak Alquran diturunkan sekitar lebih dari 14 abad yang lalu. Terhitung mulai dari ayat pertama diturunkan yaitu Q.S. 96, Al-'Alaq; 1-5 pada Bulan Ramadan (dengan perbedaan tanggal, diantaranya berpendapat; tanggal 17 Ramadan atau 13 tahun sebelum hijriah dipercaya sebagai waktu turunnya Alquran)

(https:// umma.id/article/share/id/10 02/863246).

Kata sakinah sering dilekatkan pada kata keluarga, sehingga tergabung menjadi kata 'keluarga sakinah'. Kaum muslimin pada umumnya menyebut sebuah keluarga yang tenteram dan bahagia dengan sebutan 'keluarga sakinah'. Pemahaman ini awalnya berasal dari penafsiran QS. 30, Ar-Rum; 21. (Mohamad Taufiq, Addins Quran in ms word, version 2,2,0.0, QP Taufiqproduct).

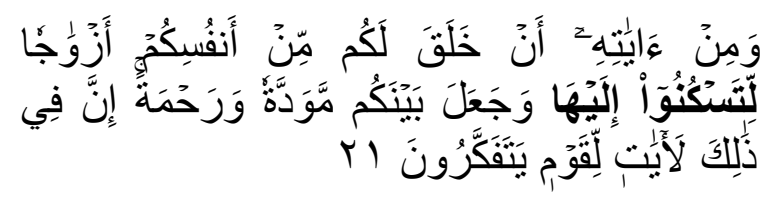

21. Dan di antara tanda-tanda kekuasaan-Nya ialah Dia menciptakan untukmu isteri-isteri dari jenismu sendiri, supaya kamu cenderung dan merasa tenteram kepadanya, dan 
dijadikan-Nya diantaramu rasa kasih dan sayang. Sesungguhnya pada yang demikian itu benar-benar terdapat tanda-tanda bagi kaum yang berfikir.

Merujuk pada ayat tersebut di atas, kata sakinah itu ternyata diikuti oleh kata mawaddah dan rahmah, sehingga kalau disandingkan dengan kata keluarga menjadi' keluarga sakinah mawaddah wa rahmah', disingkat menjadi 'keluarga samara', dan ada juga yang menyebutnya 'keluarga samawa'.

Masyarakat pada umumnya terbiasa menyebutnya secara ringkas, menjadi 'keluarga sakinah' saja. Sering kali dalam suatu acara perkawinan, para penasihat perkawinan itu mendoakan pasangan pengantin yang baru saja membentuk sebuah keluarga, agar menjadi keluarga yang sakinah. Dan akhirnya istilah itu menjadi sangat populer di kalangan masyarakat.

$$
\text { Selanjutnya kata 'sakinah' }
$$
diadopsi kedalam bahasa Indonesia yang artinya adalah: damai, tenteram, tenang, dan bahagia (KBBI, 2018; 1343). Untuk memahami lebih rinci lagi mengenai pengertian keluarga sakinah, maka dalam tulisan ini pengertian keluarga sakinah dipecah menjadi lima bagian. Pertama pengertian keluarga, kedua pengertian sakinah, ketiga pengertian mawaddah, keempat pengertian rahmah, kelima pengertian keluarga sakinah, keenam klasifikasi keluarga sakinah, ketujuh kriteria/indicator keluarga sakinah, kedelapan tujuan dan sasaran keluarga sakinah.

\section{a. Pengertian Keluarga}

Makna keluarga secara etimologis / bahasa adalah: Ibu bapak dengan anak-anaknya, sanak saudara, kaum kerabat (KBBI, 2018; 721). Makna keluarga secara umum adalah kelompok terkecil dalam masyarakat, yang minimal terdiri atas seorang suami dan seorang istri, dan atau bisa ditambah dengan seorang atau beberapa orang anak.

Makna lainnya, keluarga adalah unit terkecil dalam masyarakat yang terdiri dari suami istri, atau suami, istri dan anaknya, atau ayah dan anaknya, atau ibu dan anaknya (UndangUndang Republik Indonesia Nomor 52 Tahun 2009, Bab I, Pasal I, Ayat 6), biasa juga disebut keluarga kecil.

Jika ada keluarga kecil, maka ada juga keluarga besar, yaitu unit terkecil dalam masyarakat yang terdiri dari suami istri, atau suami istri dan anaknya, atau ayah dan anaknya, atau ibu dan anaknya, atau keluarga sedarah dalam garis lurus ke atas atau ke bawah sampai dengan derajat ketiga (Undang-Undang Republik Indonesia Nomor 23 Tahun 2002, Bab I, Pasal 1, Ayat 3).

\section{b. Pengertian Sakinah}

Makna 'sakinah' secara etimologis / bahasa, berasal dari kata bahasa Arab, yaitu perubahan bentuk dari kata: sakana - yaskunu - sukuunan (سكن - يسكن - سكونا ), yang artinya adalah: diam, tenang, menempati. Kata: sakana - yaskunu - sukuunan ( سكن - يسكن سكونا - ), mengalami sedikit pergeseran makna ketika kata tersebut bertemu dengan sub kata lainnya, yaitu: sakana yaskunu - ilaihi (سكن - يسكن - اليه), artinya menjadi: senang, atau menaruh kepercayaan kepadanya.

Berbeda maknanya jika ada perubahan harakat (perubahan bunyi 'a', 'i', ' $u$ ') pada kata bahasa Arab tersebut, meskipun dasar hurufnya sama: sin, kaf, nun, tetapi huruf kafnya dibaca dengan ' $\mathrm{u}$ ' yaitu: sakuna - 
yaskunu (سكن - يسكن), artinya adalah: miskin (Al-Munawir, Ahmad, Warson, tt. ; 646).

Berikutnya dari kata sakana yaskunu - sukuunan (سكن - يسكن - سكونا ), tersebut, ada perubahan bentuk kata lainnya, yaitu berubah menjadi kata 'sakinah', dan diberikan sinonimnya yaitu 'tuma'ninah'. (السكينة - الطمانينة ), yang artinya: ketenangan (AlMunawir, Ahmad, Warson, tt. ; 646).

Kata 'sakinah' yang bermakna ketenangan itu, terdapat dalam QS. 48, Al-Fath; 4,

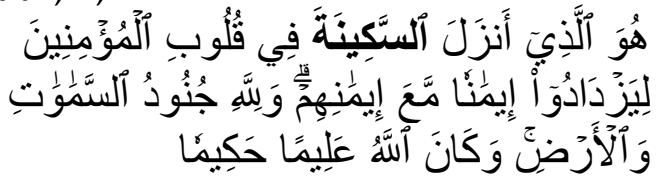

«(Tuhan yang membuka jalan kemenangan itu) Dia lah yang menurunkan perasaan semangat, tenang, tenteram ke dalam hati orang-orang yang beriman (semasa mereka meradang terhadap angkara musuh) supaya mereka bertambah iman dan yakin beserta dengan iman dan keyakinan mereka yang sudah ada; dan Allah menguasai tentara langit dan bumi (untuk menolong mereka); dan Allah adalah Maha Mengetahui, lagi Maha Bijaksana»

Beberapa makna 'sakinah' menurut para ahli tafsir pada kata 'li taskunuu ilaiha' ( لتسكنو ا اليها ), dalam QS. 30, Ar-Rum: 21 adalah:

1) Kecenderungan, kecondongan kepa-danya (Al-Alusy, Syihabuddin Mahmud bin Abdillah Al-Husainy, $\mathrm{tt} ; 348)$.

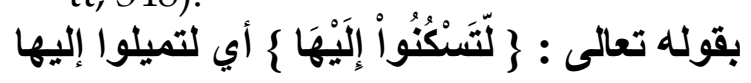

2) Berkumpul (Hayyan, Abu Hayyan Muhammad bin Yusuf bin Ali bin Yusuf, tt; 76-77).

\section{وعلل خلق الأزواج بالسكون إليها ، وهو الإلف}

3) Berkumpul, cenderung, condong (As-Syaukani, tt; 464).

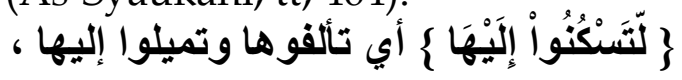

4) Berkumpul (Al-Mahalli Jalaluddin, dan As-Suyuthi Jalaluddin, tt; 429).

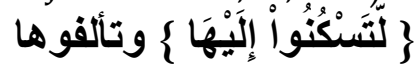

5) Jinak, ramah, senang, suka (AlMawardi, Abul Hasan Ali, bin Muhammad, bin Muhammad, bin Habibil Bisri, Al-Baghdadi, tt; 315).

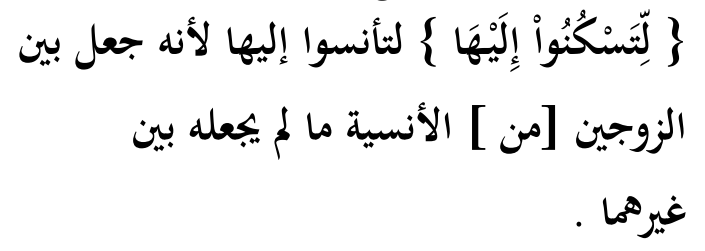

Beberapa pengertian 'sakinah' sebagaimana tersebut di atas, menunjukkan bahwa makna sakinah adalah tumbuhnya rasa kecenderungan dan ketertarikan antara orang yang berlainan jenis untuk bertemu, berkumpul, dan berdiam di suatu tempat dengan prinsip saling membutuhkan, dan saling percaya antara satu dengan yang lainnya. Prinsip tersebut jika dibina dan dikelola dengan baik dapat menjadi benih kedamaian, ketenteraman, ketenangan dan kebahagiaan.

Dua jenis manusia yang merasa saling tertarik, akan cenderung untuk saling berdekatan, dan bentuk kedekatan itu bisa secara fisik maupun psikis. Setelah merasa saling dekat, keduanya akan saling membutuhkan, karena itu keinginan berikutnya adalah berkumpul dan berdiam di suatu tempat dengan prinsip saling percaya.

\section{c. Pengertian Mawaddah}

Makna mawaddah secara etimologis berasal dari kata bahasa Arab, yang merupakan perubahan bentuk dari kata: wadda - yawaddu - wuddan/ waddan/ widdan-wudaadan /wadaadan/ widaadan - wadaadatan - mawaddatan (ود - يود - ودا - ودادا - ودادة - مودة ) yang artinya adalah: menyukai, menyenangi, 
menyayangi, menginginkan, dan mencintai (Al-Munawir, Ahmad, Warson, tt. ; 1547).

Mawaddah itu adalah rasa suka yang berkonotasi pada aspek seksual dan atau pada sesuatu yang bersifat fisik. Rasa suka yang membawa gairah ini bisa tumbuh dari aspek kecantikan atau ketampanan pasangan, kedudukan atau hal lain yang melekat pada pasangannya(Al-Alusy, Syihabuddin Mahmud bin Abdillah AlHusainy, tt; 348).

Rasa suka yang berbalut gairah ini akan membuat rumah tangga penuh warna dan dinamika (Al-Mawardi, Abul Hasan Ali, bin Muhammad, bin Muhammad, bin Habibil Bisri, AlBaghdadi, tt; 315). Tanpa adanya mawaddah bisa berkemungkinan membuat kehidupan berkeluarga serasa ada yang kurang, terutama pada masa usia produktif.

Rasa mawaddah itu membuat seseorang mau berkorban, mau memberikan sesuatu yang lebih baik untuk yang disukainya.

Pasangan yang memelihara rasa mawaddah tentunya memiliki nafsu yang yang halal dalam aspek pernikahan. Keluarga mawaddah adalah keluarga yang selalu berusaha menumbuhkan kegairahan dari semua pihak. Misalnya dengan menjaga kebersihan, kerapihan, kesehatan, kondisi tubuh, dan lain-lain.

Beberapa pengertian mawaddah sebagaimana tersebut di atas, menunjukkan bahwa antara sepasang manusia yang berlainan jenis pada umumnya jika bertemu, berkumpul, atau berdiam di suatu tempat berpeluang untuk muncul rasa ketertarikan pada aspek fisik dan seksual. Ketertarikan pada aspek fisik dan seksual bagi penulis, tidak mesti berorientasi pada hubungan kelamin saja, tetapi bisa juga ketertarikan untuk berbincang, bersenda gurau, berjalan, bepergian, makan minum, atau istirahat bersama.

Seiring dengan bertambahnya usia dan kebersamaan, maka rasa mawaddah itu akan berubah dan didominasi oleh rasa rahmah.

\section{d. Pengertian Rahmah}

Makna rahmah secara etimologis berasal dari kata bahasa Arab, perubahan bentuk dari kata: rohima yarhamu - rahmatan (رحم-يرحم-رحمة), yang artinya adalah: merasa kasihan, mengasihi, menyayangi (Al-Munawir, Ahmad, Warson, tt. ; 483).

Rahmah itu adalah rasa sayang yang berkonotasi pada aspek non fisik; mengasihi, menyayangi, menghargai, menghormati, memahami, menjaga, dan lain-lain. Seperti yang dirasakan orang tua kepada anak atau sebaliknya, seperti yang dirasakan seorang kakak terhadap adik atau sebaliknya (AlAlusy, Syihabuddin Mahmud bin Abdillah Al-Husainy, tt; 348).

Rahmah akan sulit terwujud jika salah satu pihak atau lebih, selalu atau sering menumbuhkan rasa curiga, tidak percaya, merendahkan, keras kepala, atau mau menang sendiri.

Beberapa pengertian rahmah sebagaimana tersebut di atas, menunjukkan bahwa antara sepasang manusia yang berlainan jenis pada umumnya jika bertemu, berkumpul, atau berdiam di suatu tempat, jika naluri kemanusia-annya yang dominan, bukan naluri kebinatangannya muncul, maka akan tumbuh rasa iba, kasihan, saling menghormati, menghargai, memahami, 
men-jaga, bertanggung jawab, ingin memberi dan seterusnya.

\section{e. Pengertian Keluarga Sakinah Menurut Pemerintah}

Pengertian keluarga sakinah menurut terminologi pemerintah sebagaimana disampaikan pihak kementerian agama adalah:

"Keluarga yang dibina atas perkawinan yang sah, mampu memenuhi hajat hidup spiritual dan material secara layak dan seimbang, diliputi suasana kasih sayang antara anggota keluarga dan lingkungannya secara selaras, serasi, serta mampu mengamalkan, menghayati dan memperdalam nilai-nilai keimanan, ketaqwaan dan akhlak mulia". (Kepdirjen Bimas Islam \& Urusan Haji, No. 71 Tahun 1999, Bab III, Pasal 3).

Dalam konteks ini, sebuah keluarga akan menjadi sakinah jika dapat memenuhi beberapa persyaratan sebagai berikut:

1. Perkawinannya tercatat di KUA/

Kantor Urusan Agama.

Pasangan nikah yang perkawinannya tercatat di KUA akan mendapat-kan Salinan kutipan akta nikah / buku nikah. Buku nikah ini memiliki banyak fungsi, diantaranya adalah: Pertama, bukti dan tanda keabsahan pernikahan menurut agama dan negara. Kedua, memudahkan birok-rasi untuk pengurusan tunjangan, asuransi, perjalanan, dan lain-lain. Ketiga, mendapatkan kepastian hu-kum dan hak, misalnya dana pen-siun, warisan dan yang lainnya. Keempat, kepastian pengakuan antara anak dan orang tua. Kelima, mempermudah pengurusan hak asuh anak jika terjadi perceraian.

2. Kebutuhan spiritual terpenuhi.
Kebutuhan spiritual adalah kemampuan untuk menjalankah ajaran agama secara konsisten, konsekwen, dan bebas sesuai dengan pengetahuan dan keyakinannya. Misalnya melaksanakan solat, puasa, dan yang lainnya.

3. Kebutuhan material tercukupi.

Kebutuhan material adalah fisik secara mendasar, misalnya kebutuhan berupa tempat tinggal, pakaian, dan makan minum secara normal.

4. Diliputi suasana kasih dan sayang. Suasana kekeluargaan yang penuh perhatian, penghargaan, dan perlindungan antara satu dan lainnya.

5. Mengamalkan nilai keimanan. Iman itu mesti diucapkan dengan lisan, diyakini dengan hati, dan dipraktikkan sesuai dengan syarat dan rukunnya.

(https://www.merdeka.com/gaya L5-manfaat-utama-yang-didapatdari-mencatatkan-pernikahan.html) Beberapa nilai keimanan yang harus dijalankan sesuai dengan Q.S. 23, Al-Mukminun; 2-9 adalah: a. khusyuk dalam solat. b. Meninggalkan perkataan dan perbuatan yang tidak berguna. c. Mengeluarkan zakat. d. Menjaga kemaluan. e. Menjaga amanat. f. Melaksanakan janji. g. Menjaga solat.

6. Menjalankan nilai ketakwaan.

Takwa itu merupakan buah dari iman.

Beberapa nilai ketakwaan yang harus dijalankan sesuai dengan Q.S. 2, Al-Baqarah; 3-4 adalah: a. beriman kepada yang ghaib. b. mendirikan shalat. c. berinfak. d. beriman kepada Al-Quran. e. beriman kepada kitab-kitab 
sebelum Al-Quran. f. meyakini adanya akhirat.

Beberapa nilai ketakwaan lain yang harus dijalankan sesuai dengan Q.S. 23, Ali Imran; 133-135 adalah: a. Berinfak saat lapang maupun sempit. b. Mengendalikan rasa marah. c. Memaafkan terhadap sesama. d. Beristigfar jika berbuat fahisyah/keji, atau mendzalimi diri sendiri.

Beberapa nilai ketakwaan lain yang harus dijalankan sesuai dengan Q.S. 51, Adz-Dzariyat; 15-19 adalah: a. banyak berbuat baik. b. sedikit tidur malam. c. beristigfar diwaktu sahur. d. menyisihkan sebagian hartanya untuk orang yang meminta maupun yang tidak meminta.

7. Melaksanakan perilaku akhlak mulia.

Beberapa nilai perilaku akhlak mulia yang harus dijalankan (Hasan, Said, Hamid, dkk, 2010; 910) diantaranya adalah: relijius, jujur, toleransi, disiplin, kerja keras, kreatif, mandiri, demokratis, menghargai, komunika-tif, peduli, tanggung jawab, dan lain-lain.

\section{f. Klasifikasi Keluarga Sakinah}

Keluarga sakinah menurut versi pemerintah dapat diklasifikasikan menjadi lima kelompok, terdiri dari Keluarga Pra Sakinah, Keluarga Sakinah I, Keluarga Sakinah II, Keluarga Sakinah III, dan Keluarga Sakinah III Plus.

Berikut ini adalah definisi dari masing-masing klasifikasi keluarga sakinah (Kepdirjen Bimas Islam \& Urusan Haji, No. 71 Tahun 1999, Bab III, Pasal 4).

1.Keluarga Pra Sakinah : yaitu keluarga-keluarga yang dibentuk bukan melalui ketentuan perkawinan yang sah, tidak dapat memenuhi kebutuhan dasar spiritual dan material (basic need) secara minimal, seperti keimanan, shalal, zakat fitrah, puasa, sandang, pangan, papan dan kesehatan.

2. Keluarga Sakinah I : yaitu keluargakeluarga yang dibangun atas perkawinan yang sah dan telah dapat memenuhi kebutuhan spiritual dan material secara minimal tetapi masih belum dapat memenuhi kebutuhan sosial psikologisnya seperti kebu-tuhan akan pendidikan, bimbingan keagamaan dalam keluarganya. mengikuti interaksi sosial keagamaan dengan lingkungannya.

3. Keluarga Sakinah II : yaitu keluarga-keluarga yang dibangun atas perkawinan yang sah dan disamping telah dapat memenuhi kebutuhan kehidupannya juga telah mampu memahami pentingnya pelaksanaan ajaran agama serta bimbingan keagamaan dalam keluarga serta mampu mengadakan interaksi sosial keagamaan dengan lingkungannya, tetapi belum mampu menghayati serta mengembangkan nilai-nilai keimanan, ketaqwaan dan akhlaqul karimah, infaq, zakat, amal jariah, menabung dan sebagainya.

4. Keluarga Sakinah III : yaitu keluarga-keluarga yang dapat memenuhi seluruh kebutuhan keimanan, ketaqwaan, akhlaqul karimah sosial psikologis, dan pengembangan keluarganya, tetapi belum mampu menjadi teladan bagi lingkungannya. 
5. Keluarga Sakinah III Plus : yaitu keluarga-keluarga yang telah dapat memenuhi seluruh kebutuhan keimanan, ketaqwaan dan akhlaqul karimah secara sempurna, kebutuhan sosial psikologis, dan pengembangannya serta dapat menjadi teladan bagi lingkungannya.

\section{g. Kriteria/Indikator Keluarga Sakinah}

Setiap kelompok dalam klasifikasi keluarga sakinah telah ditetapkan kriteria/ cirinya masingmasing (Direktorat Urusan Agama Islam dan Pembinaan Syariah, 2011; 2325). Berikut ini rinciannya:

\section{Keluarga Pra Sakinah :}

a. Keluarga dibentuk tidak melalui perkawinan yang sah.

b. Tidak sesuai ketentuan undang-undang perkawinan yang berlaku.

c. Tidak memiliki dasar keimanan.

d. Tidak melakukan shalat wajib.

e. Tidak rnengeluarkan zakat fitrah.

f. Tidak menjalankan puasa wajib.

g. Tidak tamat SD, dan tidak dapat baca tulis.

h. Termasuk kategori fakir dan atau miskin.

i. Berbuat asusila.

j. Terlibat perkara-perkara kriminal.

2. Keluarga Sakinah I :

a. Perkawinan sesuai dengan peraturan syariat dan UU Nomor 1 Tahun 1974. b. Keluarga memiliki Surat Nikah atau bukti lain, sebagai bukti perkawinan yang sah.

c. Mempunyai perangkat shalat, sebagai bukti melaksanakan shalat wajib \& dasar keimanan.

d. Terpenuhi kebutuhan makanan pokok, sebagal tanda bukan tergolong fakir miskin.

e. Masih sering meninggalkan shalat.

f. Jika sakit sering pergi ke dukun.

g. Percaya terhadap tahayul.

h. Tidak datang ke pengajian/ majelis taklim.

i. Rata-rata keluarga tamat atau memiliki ijazah SD.

\section{Keluarga Sakinah II :}

Telah memenuhi kriteria Keluarga Sakinah I, dan ditambah indikator berikut :

a. Tidak terjadi perceraian, kecuali sebab kematian atau hal sejenis lainnya yang mengharuskan terjadinya perceraian itu.

b. Penghasilan keluarga melebihi kebutuhan pokok, sehingga bisa menabung.

c. Rata-rata keluarga memiliki ijazah SMTP.

d. Memiliki runah sendiri meskipun sederhana.

e. Keluarga aktif dalam kegiatan kemasyarakatan dan sosial keagamaan.

f. Mampu memenuhl standard makanan yang sehat/memenuhi empat sehat lima sempuma.

g. Tidak terlibat perkara kriminal, judi, mabuk, prostitusi dan perbuatan amoral lainnya. 


\section{Keluarga Sakinah III :}

Telah memenuhi kriteria keluarga Sakinah II, ditambah indikator berikut :

a. Aktif dalam upaya meningkatkan kegiatan dan gairah keagamaan di masjid-masjid maupun dalam keluarga.

b. Keluarga aktif menjadi pengurus kegiatan keagamaan dan sosial kemasyarakatan.

c. Aktif memberikan dorongan dan motivasi untuk meningkatkan kesehatan ibu dan anak serta kesehatan masyarakat pada umumnya.

d. Rata-rata keluarga memiliki ijazah SMTA ke atas.

e. Pengeluaran zakat, infaq, shadaqah, dan wakaf senantiasa meningkat.

f. Meningkatnya pengeluaran qurban.

g. Melaksanakan ibadah haji secara baik dan benar, sesuai tuntunan agama dan ketentuan perundangundangan yang berlaku.

\section{Keluarga Sakinah III Plus:}

Telah memenuhi kriteria Keluarga Sakinah III, ditambah indikator berikut :

a. Keluarga yang telah melaksanakan haji dapat memenuhi kriteria haji mabrur.

b. Menjadi tokoh agama, tokoh masyarakat dan tokoh organisasi yang dicintai oleh masyarakat dan keluarganya.

c. Pengeluaran zakat, infaq shadaqah, jariyah, wakaf meningkat baik secara kualitatif maupun kuantitatif. d. Meningkatnya kemampuan keluarga dan masyarakat sekelilingnya dalam memenuhi ajaran agama.

e. Keluarga mampu mengembangkan ajaran agama.

f. Rata-rata anggota keluarga mempunyai ijazah sarjana.

g. Nilai-nilai keimanan, ketaqwaan dan akhlakul karimah tertanam dalam kehidupan pribadi dan keluarganya.

h. Tumbuh berkembang perasaan cinta kasih sayang secara selaras, serasi dan seimbang dalam anggota keluarga dan Iingkungannya.

i. Mampu menjadi suri tauladan masyarakat sekitamya.

\section{h. Tujuan dan Sasaran Gerakan Pembinaan Keluarga Sakinah}

Tujuan gerakan pembinaan keluarga sakinah ada dua macam, yaitu tujuan umum dan tujuan khusus (Kepdirjen Bimas Islam \& Urusan Haji, No. 71 Tahun 1999, Bab IV, Pasal 5, Ayat 1 dan 2), Tujuan umum yang pertama adalah meningkatkan kualitas sumber daya manusia secara terpadu antara masyarakat dan pemerintah dalam rangka percepatan pengendalian dan upaya mengatasi krisis moral yang bersifat nasional. Kedua adalah berupaya mewujudkan masyarakat madani yang penuh keimanan, ketakwaan dan akhlak mulia. Berikutnya adalah tujuan khusus gerakan pembinaan keluarga sakinah terdiri atas lima poin.

1) Menanamkan nilai keimanan, ketakwaan dan akhlak mulia melalui pendidikan agama dalam keluarga, masyarakat, dan pendidikan formal. 
2) Memberdayakan ekonomi umat melalui peningkatan kemampuan ekonomi keluarga, kelompok keluarga sakinah, koperasi masjid, koperasi majelis taklim, dan upaya peningkatan ekonomi kerakyatan lainnya, serta memobilisasi potensi zakat, infaq, dan shadaqah.

3) Meningkatkan gizi masyarakat melalui pembinaan calon pengantin, ibu hamil dan menyusui, bayi, balita, dan anak usia sekolah dengan pendekatan agama.

4) Meningkatkan kesehatan keluarga, masyarakat dan lingkungan melalui pendekatan agama dan jumat bersih.

5) Meningkatkan upaya penanggulangan penyakit menular seksual dan HIV/AIDS melalui pendekatan moral keagamaan.

Sasaran gerakan pembinaan keluarga sakinah adalah seluruh keluarga dan masyarakat Indonesia pada umumnya dan khususnya keluarga miskin.

\section{KESIMPULAN}

Memiliki keluarga yang sakinah adalah dambaan setiap insan, tapi tidak semua orang dapat memahami cara untuk mewujudkannya, kalaupun ada yang memahaminya belum tentu mau melaksanakan apa yang dipahaminya itu, dan walaupun ada yang mau melaksanakan apa yang dipahaminya itu, belum tentu mampu pula untuk melaksanakannya. Karena untuk dapat mewujudkan keluarga yang sakinah, tidak cukup hanya dengan pemahaman, dan kemauan saja, tapi juga dibutuhkan lingkungan dan suasana yang baik serta kerjasama kuat yang berkesinambung-an dari pasangan suami istri.

Keluarga yang sakinah itu secara fitrah manusiawi harus direncanakan dengan baik, dan mesti diusahakan semaksimal mungkin untuk melakukan berbagai upaya demi meraihnya sejak proses sebelum perkawinan, dan selama perkawinan berlangsung hingga akhir hayat.

Konsep keluarga sakinah adalah keluarga bahagia yang berinteraksi dengan pola saling membutuhkan, mencintai, mengasihi, dan menyayangi secara berimbang, berdiri di atas perkawinan yang sah, dengan kemampuan untuk menjalankan kewajiban dan haknya, diiringi dengan ketaatan pada ajaran agama dan hukum negara.

Konsep tersebut merupakan suatu pengetahuan yang harus dipahami secara mendalam, diiringi dengan kemauan kuat untuk mempraktikkannya, dan kemampuan yang maksimal untuk melaksanakannya.

\section{Saran}

Keluarga yang sakinah mawaddah wa rahmah adalah sebuah konsep yang memerlukan kecerdasan dan perjuangan untuk mewujudkannya. Karena itu kepada yang berniat untuk memiliki keluarga bahagia itu, hendaknya dapat memilih dan memilah siapa yang akan dijadikan pasangan hidup hingga akhir hayatnya. Selanjutnya bekerja sama untuk merawat cinta dan kasih sayangnya supaya tetap tumbuh dengan subur. 
Wawasan:

Jurnal Kediklatan Balai Diklat Keagamaan Jakarta

PISSN: 2548-9232; ${ }_{\mathrm{E}}$ ISSN: 2775-3573

Volume 2 Nomor 1 Tahun 2021: 16-31

\section{DAFTAR PUSTAKA}

Al-Alusy, Syihabuddin Mahmud bin Abdillah Al-Husainy (tt.), Ruhul Ma'ani fi Tafsiril Quranil 'Adzim was Sab'il Matsani, tp, Maktabah Syamilah, Softcopy, http://www.altafsir.com

Al-Mawardi, Abul Hasan Ali, bin Muhammad, bin Muhammad, bin Habibil Bisri, AlBaghdadi (tt.), An-Naktu Wal Uyun, tp, Maktabah Syamilah, Softcopy, http://www.altafsir.com

Al-Mahalli Jalaluddin, dan As-Suyuthi Jalaluddin (tt.), Tafsir Jalalain, tp, Maktabah Syamilah, Softcopy, http://www.altafsir.com

Al-Munawwir, Ahmad, Warson (tt.), Kamus Al-Munawwir Arab-Indonesia Terlengkap, tp, Softcopy. http://www.kampungsunnah.org,

Andinim Ayu. (2019). Diakses di https://lokadata.id/artikel/tingkat-perceraianlebih-tinggi-dari-perkawinan

Artiyono, Sabar, dkk. (2019). Diakses di https://kumparan.com/kumparannews/kami-membandingkan-jumlahpernikahan-dan-perceraian-di-indonesia-1sKM5fAHafr/full

As-Syaukani (tt.), Fathul Qodir, tp, Maktabah Syamilah, Softcopy, http://www.altafsir.com

Direktorat Urusan Agama Islam dan Pembinaan Syariah. (2011). Petunjuk Teknis Gerakan Pembinaan Keluarga Sakinah. Jakarta: Kementerian Agama RI, Direktorat Jenderal Bimbingan Masyarakat Islam/Dirjen Bimas Islam, Softcopy. ok

Falahudin, I. (2020). Kompetensi Pengetahuan Pembina Gerakan Keluarga Sakinah. Wawasan: Jurnal Kediklatan Balai Diklat Keagamaan Jakarta, 1(1), 110-117.

Hayyan, Abu Hayyan Muhammad bin Yusuf bin Ali bin Yusuf (tt.), Tafsirul Bahril Muhit, tp, Maktabah Syamilah, Softcopy, http://www.altafsir.com

Hasan, Said, Hamid, dkk. (2010). Pengembangan Pendidikan Budaya dan Karakter Bangsa, Jakarta, Kementerian Pendidikan Nasional, Badan Penelitian dan Pengembangan, Pusat Kurikulum.

Instruksi Presiden Republik Indonesia Nomor 3 Tahun 1997, Tentang Penyelenggaraan Pembinaan Kualitas Anak, Softcopy.

Keputusan Menteri Agama Republik Indonesia Nomor 3 Tahun 1999 Tentang Pembinaan Gerakan Keluarga Sakinah, softcopy.

Keputusan Direktorat Jenderal Bimbingan masyarakat Islam/ Kepdirjen Bimas Islam, \& Urusan Haji, No. 71 Tahun 1999, Tentang Petunjuk Pelaksanaan Pembinaan Gerakan Keluarga Sakinah, Softcopy.

Mohamad Taufiq, Addins Quran in ms word, version 2,2,0.0, QP Taufiqproduct, tt, softcopy, https://www.facebook.com/QuranInMsWord 
Wawasan:

Jurnal Kediklatan Balai Diklat Keagamaan Jakarta PISSN: 2548-9232; EISSN: 2775-3573

Volume 2 Nomor 1 Tahun 2021: 16-31

Nasrudin,

Achmad.

(2020).

Diakses

di

https://nasional.kompas.com/read/2020/09/13/10294341/tekan-angka-

perceraian-kemenag-jalin-sinergitas-penguatan-ketahanan-keluarga?page $=$ all

Pusat Bahasa Jakarta (2008), Kamus Bahasa Indonesia, Jakarta, Pusat Bahasa Departemen Pendidikan Nasional, Softcopy.

Pusdiklat Teknis Pendidikan dan Keagamaan (2018), Dokumen II Kurikulum Diklat Teknis Substantif Keagamaan, 178 Diklat Teknis Substantif Keluarga Sakinah Kepala KUA K.I.A.j.1. Ciputat, Tangerang Selatan, Softcopy.

Sugema Sony, Digitalquran, ver. 3.1, tp, 2003-2004, softcopy,

http://www.geocities.com/sonysugema2000

Rusdiana. (2015). Manajemen Konflik, Bandung: Pustaka Setia.

Setyorini, Tantri. (2015) Diakses di https://www.merdeka.com/gaya/5-manfaatutama-yang-didapat-dari-mencatatkan-pernikahan.html

Sumara, Dadan, dkk. (2017). Diakses di

http://journal.unpad.ac.id/prosiding/article/viewFile/14393/6947

Susan, Novri. (2014). Pengantar Sosiologi Konflik, Jakarta: Kencana.

Syarifah,

Mar'atus.

(2018).

Diakses

di

https://nationalgeographic.grid.id/read/13900431/pernikahan-yang-tidak-

harmonis-berdampak-buruk-pada-kesehatan

Titania, Adisty, Diakses di https:/ / id.theasianparent.com/konflik-rumah-tangga

Undang - Undang Republik Indonesia Nomor 1 Tahun 1974, Tentang Perkawinan, Softcopy.

Undang-Undang Republik Indonesia Nomor 23 Tahun 2002, Tentang Perlindungan Anak, Softcopy.

Undang-Undang Republik Indonesia Nomor 52 Tahun 2009, Tentang Perkembangan Kependudukan dan Pembangunan Keluarga, Softcopy.

Undang-Undang Republik Indonesia Nomor 23 Tahun 2006 Tentang Administrasi Kependudukan, Softcopy.

https://umma.id/article/share/id/1002/863246

http://indonesiabaik.id/infografis/jumlah-kasus-perceraian-di-indonesia-

memprihatinkan 